\title{
A new freshwater Psammodictyon species in the Taihu Basin, Jiangsu Province, China
}

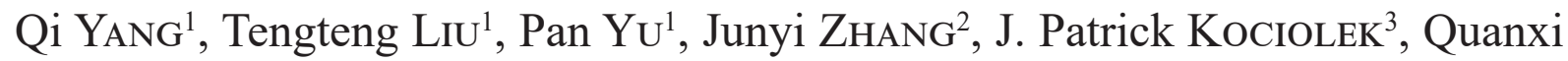 \\ WANG \& Qingmin You $^{1 *}$
}

\author{
${ }^{1}$ College of Life Sciences, Shanghai Normal University, Shanghai 200234, China; *Corresponding author e- \\ mail:youqm1117@shnu.edu.cn \\ ${ }^{2}$ Jiangsu Wuxi Environmental Monitoring Center, Wuxi 214121, China \\ ${ }^{3}$ Museum of Natural History and Department of Ecology and Evolutionary Biology, University of Colorado, \\ Boulder, CO 80309, USA
}

\begin{abstract}
We describe a new species of diatom, Psammodictyon taihuensis sp. nov., collected from the Taihu Basin, Jiangsu Province, China. There are several features of this diatom that suggest it should be included in the genus Psammodictyon, notably the possession of panduriform valves characterized by a longitudinal fold near the apical axis, coarsely areolate striae, and a keeled raphe system present on the valve margin. This species is distinct from others in the genus by its small size, being only $16.5-25.0 \mu \mathrm{m}$ long and $10.0-12.5 \mu \mathrm{m}$ wide in the central region, and with the widest valve being $10.5-13.5 \mu \mathrm{m}$ in width. There are $8-11$ distinct fibulae per $10 \mu \mathrm{m}$ and the striae are composed of 18-22 coarse areolae per $10 \mu \mathrm{m}$. This is the first report of a freshwater member of the genus Psammodictyon in China, which expands the known geographical and ecological distributions of the genus and enhances our understanding of freshwater diatom diversity in China.
\end{abstract}

Key words: diatom, new species, Psammodictyon, Taihu Lake, taxonomy

\section{INTRODUCTION}

The genus Psammodictyon D.G. Mann (in Round et al. 1990) was established mainly based on Nitzschia sect. Panduriformes Grunow, as well as several species of Tryblionella W. Smith. This is a small genus comprising less than 20 taxa recorded to date (GUIRY \& GUIRY 2019; KocioleK et al. 2019). The genus was originally characterized as predominantly marine in origin (RouND et al. 1990) and all taxa included in the genus are known from marine waterbodies, with the exception of the type species Psammodictyon panduriforme (Gregory) D.G. Mann, which was recorded by DAY et al. (1995) in a nonmarine waterbody in Australia. It is worth mentioning that no new taxa in this genus has been described since the 1970s, although several studies have been conducted recently (LobBan 2015; LOUVROU \& ECONOMOU-AMILLI 2012; JoHn 2016, 2018).

Although Round et al. (1990, p. 612) proposed establishment of the genus Psammodictyon, the combination of features used in its diagnosis include no unique characters. However, there are several features found in all members of the genus. Notably, the panduriform or broadly linear valves, with a raphe arranged on opposing sides of the valves of the frustule (similar to the diagonal symmetry of other members of the family Nitzschiaceae). The valve surface is undulate (similar to that of Tryblionella), and the keel is separated by a central nodule. The areolae are large, round, polygonal, and/or irregular in shape, and distinctive when viewed under a light microscope. The most advalvar girdle band typically bears two to several transverse rows of small round poroids (Round et al. 1990).

Three marine species of Psammodictyon have been reported from China, namely, $P$. panduriforme (Gregory) D.G. Mann (N. panduriformis Gregory) in the Xisha islands, Sanya, Beihai, Qingdao, and the East China Sea (JIN 1982); P. corpulentum (Hendey) D.G. Mann ( $N$. corpulenta Hendey) in Fujian and Zhejiang (JIN 1982); and P. constrictum (Gregory) D.G. Mann (N. constricta Gregory) in the Qiongzhou Strait, Hong Kong, Sanya, and the South China Sea (Jin et al. 1992). Currently, no freshwater species of this genus have been reported from China.

During the investigation of freshwater diatom diversity in the Taihu Basin, we observed a new species Psammodictyon taihuensis sp. nov. The purpose of this study was to document and formally describe the species based on light microscopy (LM) and scanning electron 
microscopy (SEM) observations, and to compare it with morphologically similar taxa. To the best of our knowledge, this is the first record of a Psammodictyon taxon from a freshwater habitat in China.

\section{Material ANd Methods}

For this study we observed samples that were collected from Taihu Basin, which includes Taihu Lake (30 $55^{\prime} 40^{\prime \prime}-31^{\circ} 32^{\prime} 58^{\prime \prime} \mathrm{N}$, $\left.119^{\circ} 52^{\prime} 32^{\prime \prime}-120^{\circ} 36^{\prime} 10^{\prime \prime} \mathrm{E}\right)$, Taipu River $\left(30^{\circ} 0^{\prime} 52^{\prime \prime}-30^{\circ} 01^{\prime} 46^{\prime \prime} \mathrm{N}\right.$, $\left.120^{\circ} 49^{\prime} 42^{\prime \prime}-121^{\circ} 04^{\prime} 19^{\prime \prime} \mathrm{E}\right)$, and Yangcheng Lake (31 $21^{\prime} 24^{\prime \prime}-$ $\left.31^{\circ} 29^{\prime} 50^{\prime \prime} \mathrm{N}, 120^{\circ} 39^{\prime} 27^{\prime \prime}-120^{\circ} 50^{\prime} 34^{\prime \prime E}\right)$, located in the Jiangsu Province (Fig 1). Taihu Lake, located in the southern edge of the Yangtze River Delta, is the third largest freshwater lake in China. The Taipu River, which is $57.2 \mathrm{~km}$ long, is an important river of the Taihu Lake Basin. It is formed by the merging of Taihu Lake with the Huangpu River. Yangcheng Lake is one of the lower reaches of the Taihu Lake. In the field, several water chemistry characteristics were recorded, including: $\mathrm{pH}$, habitat, longitude and latitude, temperature and dissolved oxygen (table 1). These were all measured using a YSIPro Plus multiparameter meter (YSI, Ohio, USA). Diatom samples were collected from natural substrates, including stones, or from navigation buoys, by clean toothbrushes, and the samples were placed in a bottle and preserved with formalin ( $4 \%$ final concentration). Several samples of planktonic and epilithic diatoms were collected in January, April and May of 2018.

In the laboratory, samples were treated with concentrated nitric acid using the Microwave Accelerated Reaction System (Model MARS, CEM Corporation, Charlotte, USA) and a pre-programmed digestion scheme (temperature: $180^{\circ} \mathrm{C}$, ramp: $15 \mathrm{~min}$, hold: $15 \mathrm{~min}$ ). Cleaned diatoms were mounted in Naphrax ${ }^{\circledR}$ as following the procedure described in You et al. (2017) for light microscopy (LM) analysis or otherwise spread on aluminum foil and mounted onto stubs for scanning electron microscopy (SEM). LM observations were made with an Olympus BX53 microscope fitted with DIC optics (100× objective, numerical aperture 1.4) and SEM examination was conducted using a Hitachi SU 8010 scanning electron microscope (2 kv) (Hitachi, tokyo, Japan).

\section{RESULTS}

Psammodictyon taihuensis Q. Yang, Q-M. You et Q-X. Wang sp. nov. (Figs 2-23)

Description: Valves panduriform, constricted in median region, with a longitudinal fold near apical axis. Valve length $16.5-25.0 \mu \mathrm{m}$, valve width in median region $10.0-12.5 \mu \mathrm{m}$, and widest part of the valve measures $10.5-13.5 \mu \mathrm{m}$. Keeled raphe system present on valve margin, with 8-11 distinct fibulae per $10 \mu \mathrm{m}$. Central two fibulae more distant from others. Striae uniseriate, comprising 18-22 coarse areolae per $10 \mu \mathrm{m}$. Striae in median region of valves parallel, radiate at the ends.

SEM observations of valve exterior show valves with one unornamented longitudinal fold near apical axis (Fig. 14, see arrow A). Raphe present on valve margin;

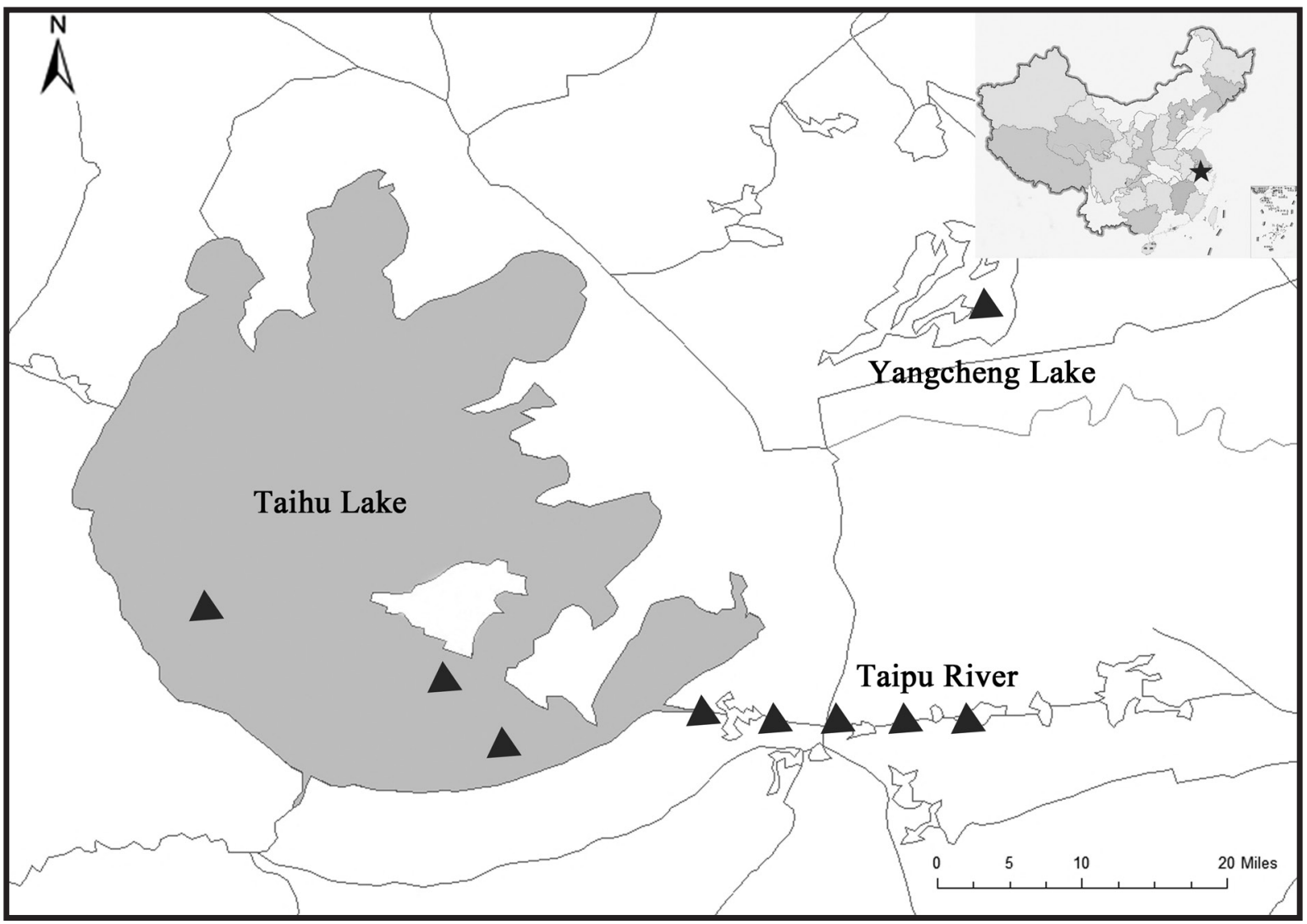

Fig 1. Location of sampling sites in the Taihu Basin. 
Table 1. Sampling sites and their geographical and chemical characteristics [(WT) Water temperature, (DO) Dissolved oxygen].

\begin{tabular}{|c|c|c|c|c|c|c|}
\hline Sample number & Collection site & Habitat & Longitude and latitude & WT $\left({ }^{\circ} \mathrm{C}\right)$ & pH & DO $\left(\mathrm{mg.l}^{-1}\right)$ \\
\hline JS-TH20180120 & Taihu Lake & Planktonic & $31^{\circ} 2^{\prime} 46^{\prime \prime} \mathrm{N}, 120^{\circ} 17^{\prime} 16^{\prime \prime} \mathrm{E}$ & 2.3 & 7.35 & 13.9 \\
\hline JS-TH20180516 & Taihu Lake & Planktonic & $31^{\circ} 8^{\prime} 11^{\prime \prime} \mathrm{N}, 120^{\circ} 0^{\prime} 42^{\prime \prime} \mathrm{E}$ & 22.4 & 8.15 & 8.73 \\
\hline JS-TH20180521 & Taihu Lake & Planktonic & $30^{\circ} 58^{\prime} 45^{\prime \prime} \mathrm{N}, 120^{\circ} 18^{\prime} 0^{\prime \prime} \mathrm{E}$ & 23.8 & 8.07 & 8.37 \\
\hline JS-20180101 & Hengshan, Taipu River & Periphyton & $31^{\circ} 0^{\prime} 42^{\prime \prime} \mathrm{N}, 120^{\circ} 32^{\prime} 36^{\prime \prime} \mathrm{E}$ & - & - & - \\
\hline JS-20180104 & Lilidong, Taipu River & Periphyton & $31^{\circ} 0^{\prime} 12^{\prime \prime} \mathrm{N}, 120^{\circ} 44^{\prime} 39^{\prime \prime} \mathrm{E}$ & 8.5 & 7.9 & 9.46 \\
\hline JS-20180401 & Hengshan, Taipu River & Periphyton & $31^{\circ} 0^{\prime} 42^{\prime \prime} \mathrm{N}, 120^{\circ} 32^{\prime} 36^{\prime \prime} \mathrm{E}$ & - & - & - \\
\hline JS-20180402 & Meiyan, Taipu River & Periphyton & $31^{\circ} 0 ' 22^{\prime \prime} \mathrm{N}, 120^{\circ} 36^{\prime} 3^{\prime \prime} \mathrm{E}$ & - & - & - \\
\hline JS-20180403 & Pingwang, Taipu River & Periphyton & $30^{\circ} 59^{\prime} 58^{\prime \prime N}, 120^{\circ} 38^{\prime} 51 " \mathrm{E}$ & 8.1 & 7.92 & 10.75 \\
\hline JS-20180405 & Fenhu, Taipu River & Periphyton & $31^{\circ} 1^{\prime} 36^{\prime \prime} \mathrm{N}, 120^{\circ} 50^{\prime} 29^{\prime \prime} \mathrm{E}$ & - & - & - \\
\hline JS-201910YCH & Yangcheng Lake & Planktonic & $31^{\circ} 24^{\prime} 47^{\prime \prime N}, 120^{\circ} 49^{\prime} 32^{\prime \prime} \mathrm{N}$ & 28.9 & 7.98 & 8.56 \\
\hline
\end{tabular}

central raphe ends slightly expanded and disconnected (Fig. 14, see arrow B) with simple terminal raphe ends (Fig. 14, see arrow C). Grooves found on both sides of valve, continuous in the centre and ending near terminal raphe ends (Fig. 14, see two arrows D). Areolae externally non-uniform, being $\mathrm{C}$-shaped near raphe margin, and bone-shaped or zigzag on other margins (Figs 14, 15). Girdle bands 2-4 (mostly 3), discontinuous at both poles (Fig. 16, see arrows). Two rows of misaligned areolae on girdle band (Fig. 16). Mantle striated with one row of coarse areolae, with 22 striae per $10 \mu \mathrm{m}$ (Fig. 15, see arrow).

Internally, valves irregular, with one unornamented longitudinal fold near the apical axis (Fig. 17, see arrow A). Number of striae between central two fibulae generally 4 , and typically 2 (occasionally 1 or 3 ) between other two fibulae (Fig. 17). Areolae small, rounded, and occluded with rows of fine openings (Fig. 18). Raphe terminates at apices in small helictoglossae. Several (generally 5 or 6) occluded depressions present near helictoglossa (Figs 19-23, see arrows).

Holotype: SHTU!, slide JS-20180405!, Lab of Algae and Environment, College of Life Sciences, Shanghai Normal University, China, holotype illustrated in Fig. 2. Isotypes: COLO! Material 650043, Kociolek Collection, University of Colorado, Museum of Natural History Diatom Herbarium, Boulder, USA.

Type locality: CHINA. Taipu River, Jiangsu Province, $31^{\circ} 1$ '36"N, 12050'29"E. The new species was found on the Fenhu Lake beside Taipu River in the Fenhu Town, Suzhou, collected by Q.X. Wang et al., April of 2018. Etymology: The species is named for Taihu Basin.

Ecology: Planktonic diatoms collected in Taihu Lake (JS-TH20180120; JS-TH20180516; JS-TH20180521), epilithic diatoms collected in Taipu River (JS-20180101; JS-20180104; JS-20180401; JS-20180402; JS-20180403;
JS-20180405) and Yangcheng Lake (JS-201910YCH). For detailed collection information see Table 1.

Distribution: So far, the new species is known only from Taihu Basin.

\section{DISCUSSION}

Members of the genera Psammodictyon and Tryblionella were previously considered to belong to the genus Nitzschia, and accordingly possess certain similar morphological characters, including the symmetry of the raphe on a frustule, wide valves, a longitudinal fold, and an eccentric raphe. They are distinguishable with respect to the structures of the valve, raphe, and fibula, and to a lesser extent by habitat, valve shape, and plastid position (Round et al. 1990). However, there appear to be no unique features that can be used to diagnose Psammodictyon, and a formal analysis of morphological features remains to be undertaken. We believe that the main features that differentiate Psammodictyon from Tryblionella are the valve outline and the structure and arrangement of the areolae. The valves of Psammodictyon species are panduriform and distinctively centrally constricted, and the areolae are coarse and less dense. The uniseriate striae have a regular arrangement of areolae in three directions (the direction of the transapical axis, and positive and negative $45^{\circ}$ vs. transapical axis, see Fig. 9 a, b, c). The main features of Tryblionella species are valves that are linear-lanceolate to elliptic in shape, and only slightly centrally constricted. The areolae are fine and more dense and there are single or double rows of striae with a regular arrangement of areolae only in the direction of the transapical axis (Round et al. 1990; SPAULDING 2011; WANG \& You 2018). In a phylogenetic analysis of members of the Bacillariaceae using two 


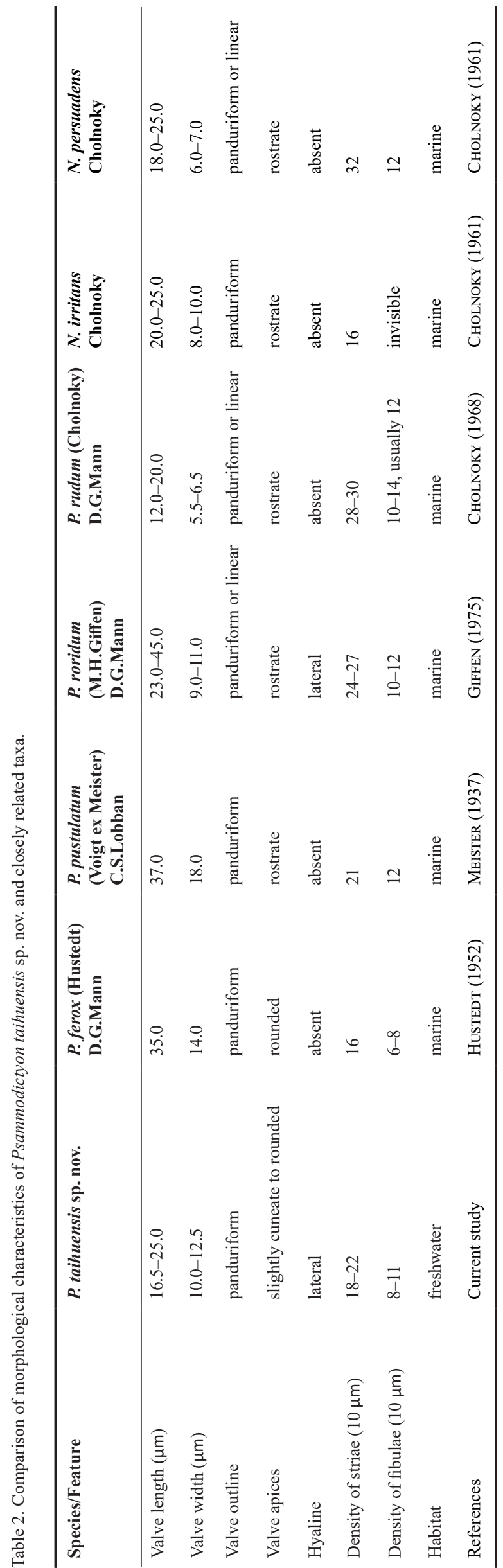

distinct genes (rbcL and LSU rDNA), CARBALlEIRA et al. (2017) and BARKIA et al. (2019) found Tryblionella and Psammodictyon to cluster in distinct clades within the family. Rimet et al. (2011) obtained similar results based on molecular analysis of the Bacillariaceae using $18 \mathrm{~S}$ rDNA. These findings tend to indicate that the similarities between Tryblionella and Psammodictyon in terms of valve shape and the presence of a longitudinal fold are a consequence of the independent evolution of these features.

The morphology of Psammodictyon taihuensis is unique among similar species in the genus with respect to valve outline, size, striae, and structure of the fibulae. Although morphologically similar to P. ferox (Hustedt) D.G. Mann in Round et al. (1990) and P. pustulatum (Voigt ex Meister) C.S. Lobban, the new species is smaller than these two species. Psammodictyon roridum (M.H. Giffen) D.G. Mann in Round et al. (1990) differs from P. taihuensis sp. nov. mainly in shape (panduriform or linear), valve length $(23-45 \mu \mathrm{m})$, stria density (24-27 per $10 \mu \mathrm{m}$ ), and in having rostrate apices (GIFFEN 1975), whereas Psammodictyon rudum (Cholnoky) D.G. Mann in Round et al. (1990) differs from P. taihuensis sp. nov. in shape (panduriform or linear) and the presence of apiculate poles, denser striae (28-30 per $10 \mu \mathrm{m})$, and narrower valves (width 5.5-6.5 $\mu \mathrm{m}$ ) (CHOLNOKY 1968). There are also some similar species in Nitzschia, among which $N$. irritans Cholnoky differs from P. taihuensis sp. nov. mainly with respect to valve apices (distinct rostrate), valve width $(8-10 \mu \mathrm{m})$, and stria density (16 per $10 \mu \mathrm{m})$ (CHOLNOKY 1961), whereas $N$. persuadens Cholnoky in CHOLnOKy (1961) differs from P. taihuensis sp. nov. in terms of shape (panduriform or linear), narrower valves (width 6-7 $\mu \mathrm{m}$ ), and denser striae (32 per $10 \mu \mathrm{m})$. Moreover, in contrast to these other species, which are all marine in origin, the new species is found in freshwater habitats. Additional details regarding the comparison between $P$. taihuensis and these morphologically similar taxa are shown in Table 2. On the basis of these comparisons, we can propose a geographical expansion of the genus Psammodictyon into freshwater ecosystems in China.

Species now included in Psammodictyon were first reported more than a hundred years ago, including the type species of the genus P. panduriforme (Gregory) D.G. Mann and P. constrictum (Gregory) D.G. Mann, both of which are widely distributed in marine habitats in Europe (Gregory 1855; KunTZE 1898; Hendey 1964; Pankow 1976; Sims 1996), North and South America (Frenguelli 1941; LobBAn 2015), and the coast of China (JIN 1982; JIN et al. 1992). The species of this genus appear to be very rare in freshwaters habitats, with only P. panduriforme (Gregory) D.G. Mann being reported from Australian inland waters (DAY et al. 1995). The new species is widely distributed in the freshwater environment of the Taihu Basin and is the first described Psammodictyon species from a freshwater habitat in China. However, it remains unclear whether this species 

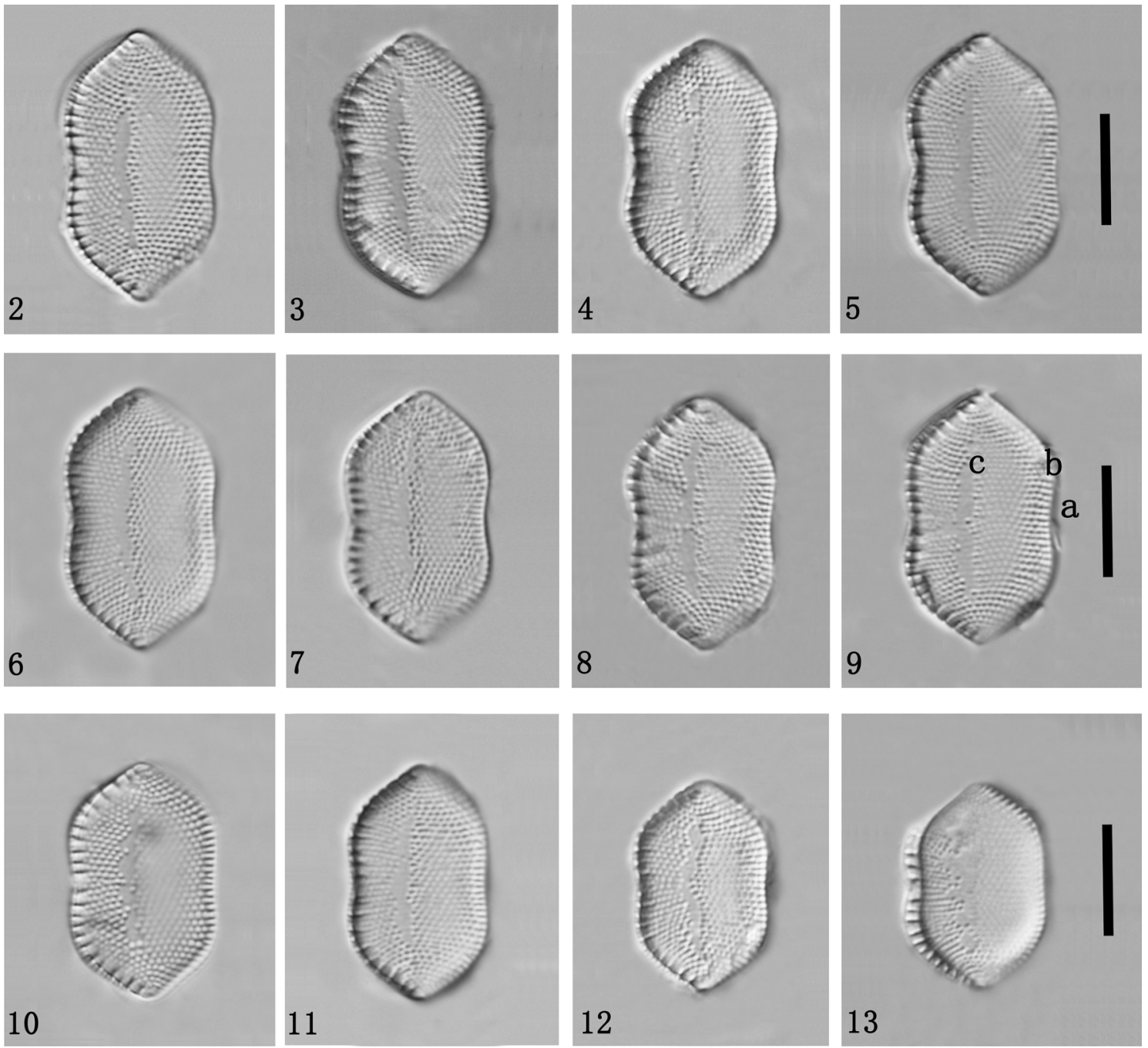

Figs 2-13. LM valve views of Psammodictyon taihuensis sp. nov.: (9 a, b, c) a regular arrangement of areolae in three directions, the direction of the transapical axis, and positive and negative $45^{\circ}$ vs. transapical axis. Scale bar $10 \mu \mathrm{m}$.

migrated inland from coastal waters or whether it has uniquely evolved in freshwater habitats in China.

\section{ACKNOWLEDGEMENTS}

This research was funded and supported by National Natural Science Foundation of China (No. 31770222) and Shanghai Engineering Research Center of Plant Germplasm Resources (17DZ2252700). Also, we are grateful for the comprehensive comments from reviewers and editor in relation to scientific aspects, format and language.

\section{REFERENCES}

BARKIA, I.; Li, C.L.; SAARI, N. \& ANDRZEJ, W. (2019): Nitzschia omanensis sp. nov., a new diatom species from the marine coast of Oman, characterized by valve morphology and molecular data. - Fottea 19: 175-184. DOI: 10.5507/fot.2019.008.

Carballeira, R.; Trobajo, R.; Leira, M.; Benito, X.; Sato, S. \& MANN, D.G. (2017): A combined morphological and molecular approach to Nitzschia varelae sp. nov., with discussion of symmetry in Bacillariaceae. - European Journal of Phycology 52: 342-359.
Cholnoky, B.J. (1961): Ein Beitrag zur Kenntnis der Diatomeenflora der venetianischen Lagunen. Hydrobiologia 17: 287-325, 90 figs.

Cholnoky, B.J. (1968): Die Diatomeenassoziationen der Santa-Lucia-Lagune in Natal (Südafrika). - Botanica Marina, 11, 1-121.

Cholnoky, B. J. (1968): Diatomeen aus drei Stauseen in Venezuela. - Revta Biol. Lisb. 6: 235-271.

Day, S.A.; Wickham, R.P.; EnTwisle, T.J. \& Tyler, P.A. (1995): Bibliographic check-list of non-marine algae in Australia. - Flora of Australia Supplementary Series 4: i-vii, 1-276.

Frenguelli, J. (1941): Diatomeas del Río de la Plata.-Revista del Museo de la Plata, Nueva Serie, Sección Botánica 3: 213-334, 7 pls.

GifFEN, M.H. (1975): An account of the littoral diatoms from Langeban, Saldanha Bay, Cape Province, South Africa. - Botanica Marina 18: 71-95.

GREGORY, W. (1855): On some new species of British freshwater Diatomaceae, with remarks on the value of certain specific characters. - Proceedings of the Botanical Society of Edinburgh 1855: 38-41.

GreGory, W. (1857): On new forms of marine Diatomaceae found in the Firth of Clyde and in Loch Fyne, illustrated 

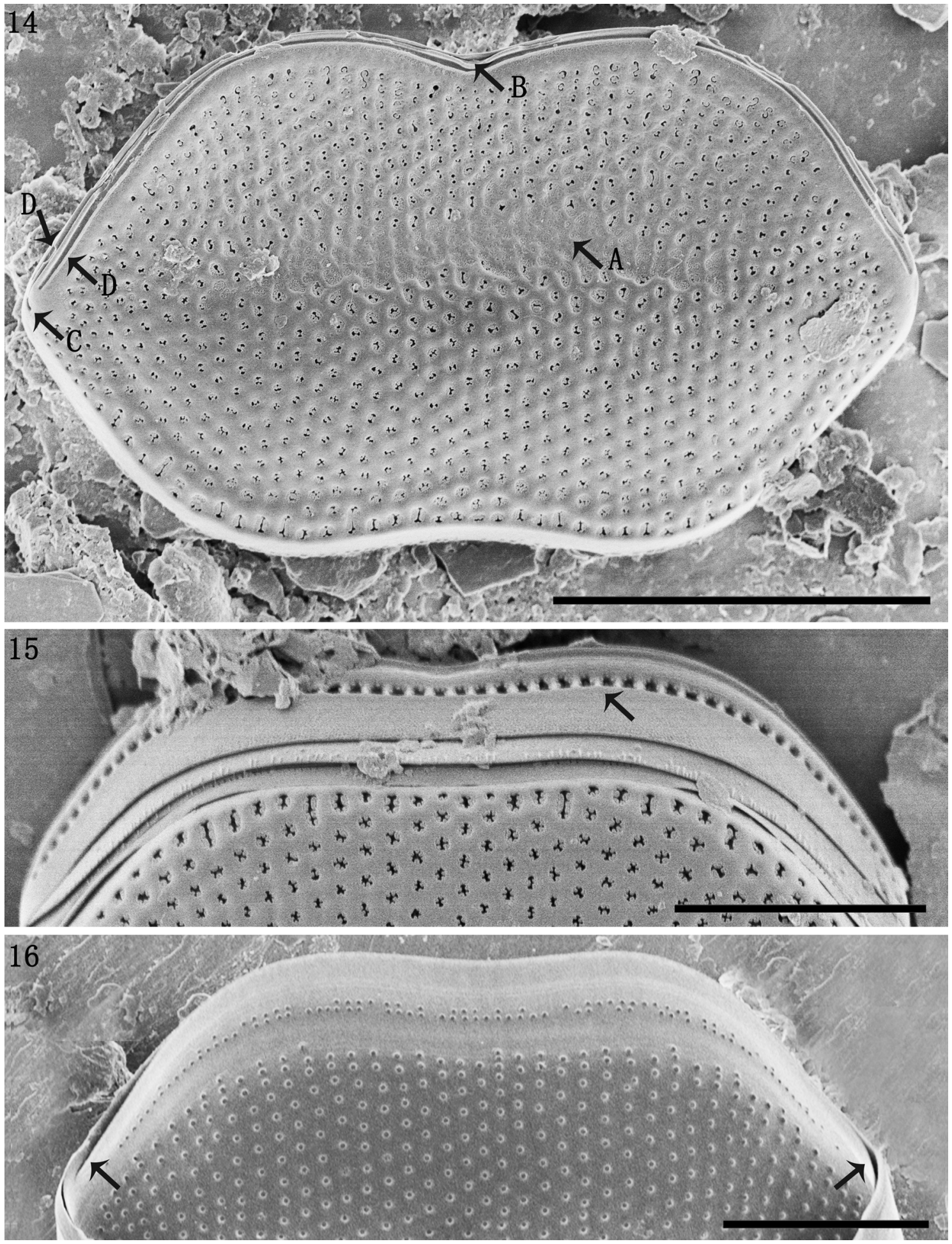

Figs 14-16. Psammodictyon taihuensis sp. nov., SEM views of valve: (14) general external view, (arrow A) one unornamented longitudinal fold, (arrow B) the central raphe, (arrow C) the terminal raphe, (arrow D) grooves on both sides of the valve; (15) external view of the band; (16) internal view of the mantle; arrow: the girdle bands. Scale bars $5 \mu \mathrm{m}(14-16)$.

by numerous figures drawn by R.K. Greville, LL.D., F.R.S.E. - Transactions of the Royal Society of Edinburgh 21: 473-542, pl. 9-14.

HENDEY, N.I. (1964): An introductory account of the smaller algae of British coastal waters. Part V: Bacillariophyceae (diatoms). - pp. [i]-xxii, 1-317, Ministry of Agriculture, Fisheries and Food, Fishery Investigations, London.
Hustedt, F. (1952): Neue und wenig bekannte Diatomeen II. - Ber. dtsch. bot. Ges. 64: 304-314.

JiN, D.X. (1982): Chinese marine benthic diatoms. - 323 pp., Ocean Press, Beijing.

JiN, D.X.; ChENG, Z.D.; Liu, S.C. \& MA, J.X. (1992): Chinese marine benthic diatoms. -437 pp., Ocean Press, Beijing. JoHN, J. (2016): Diatoms from Stradbroke and Fraser Islands, 


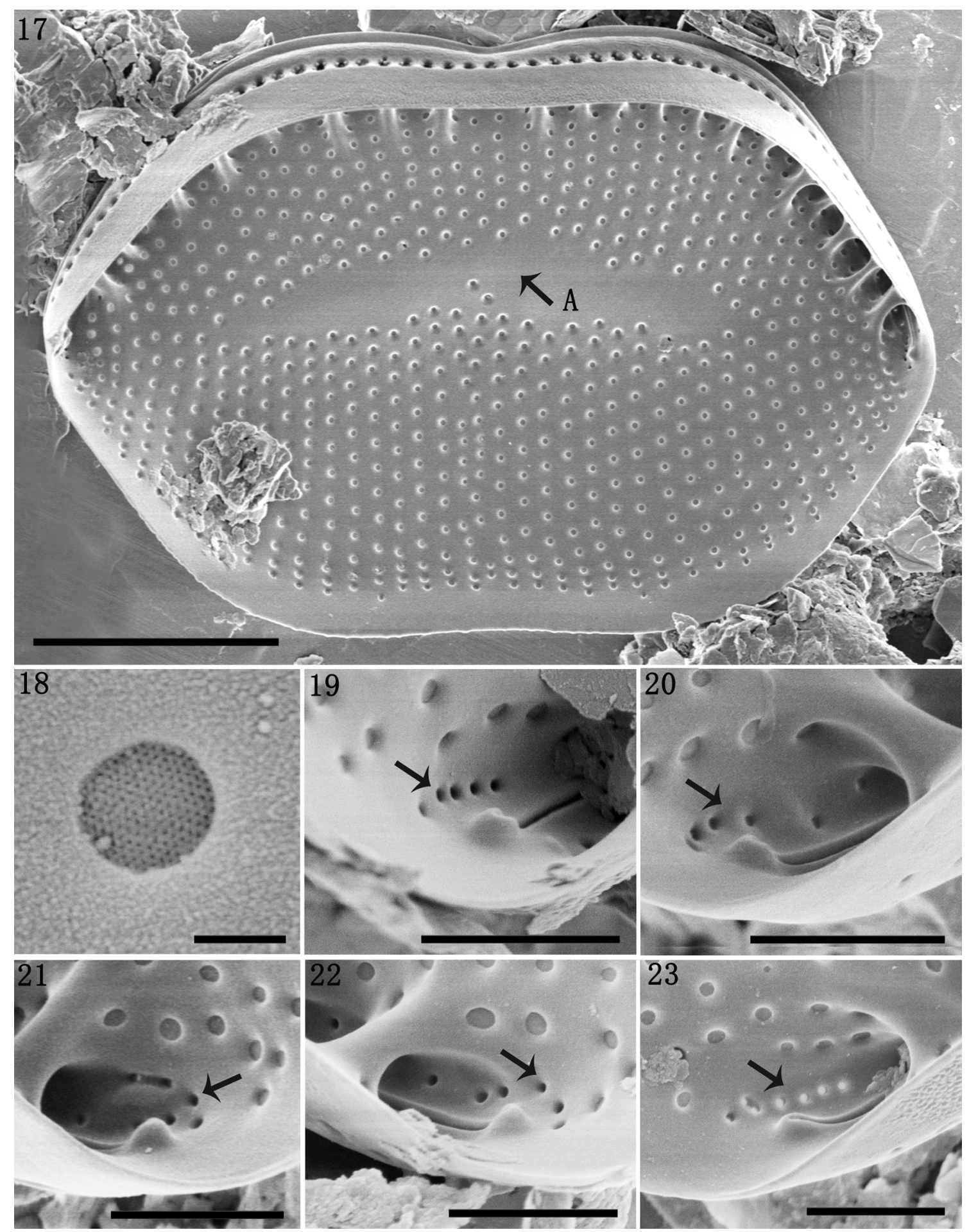

Figs 17-23. Psammodictyon taihuensis sp. nov., SEM views of valve: (17) general internal valve view, (arrow A) one unornamented longitudinal fold; (18) the details of the areolae on the internal valve; (19-23) detail of the apices on the internal valve, (arrow) occluded depressions. Scale bars $5 \mu \mathrm{m}$ (17), $0.1 \mu \mathrm{m}(18), 1 \mu \mathrm{m}(19-23)$.

Australia: taxonomy and biogeography. The diatom flora of Australia Volume 1. - pp. [1]-377, 258 figs, Koeltz Botanical Books, Schmitten - Oberreifenberg. JoHn, J. (2018): Diatoms from Tasmania: taxonomy and biogeography. The diatom flora of Australia Volume 2. - pp. [1]-656, 351 figs, Koeltz Botanical Books, Schmitten - Oberreifenberg.

Kociolek, J.P.; Balasubramanian, K.; Blanco, S.; Coste,
M.; Ector, L.; LiU, Y.; KuLIKOVSKIY, M.; LundHOLM, N.; Ludwig, T.; Potapova, M.; Rimet, F.; SABbe, K.; SAla, S.; SAR, E.; TAYlor, J.; VAN De ViJVer, B.; Wetzel, C.E.; Williams, D.M.; Witkowski, A. \& Wiткоwski, J. (2019): -In DiatomBase. - Accessed at http://www.diatombase.org on 2019-06-06.

Kuntze, O. (1898): Revisio generum plantarum. Pars III (3). - pp. 1-576, Arthur Felix, Dulau \& Co., U. Hoepli, 
Gust. A. Schechert, Charles Klincksierck, Leipzig, London, Milano, New York, Paris.

LoBBAN, C.S. (2015): Benthic marine diatom flora of Guam: new records, redescription of Psammodictyon pustulatum $\mathrm{n}$. comb., n. stat., and three new species (Colliculoamphora gabgabensis, Lauderia excentrica, and Rhoiconeis pagoensis). - Micronesica 2015: 1-49.

Louvrou, I. \& ECONOMOU-AmiLli, A. (2012): Transfer of four taxa of genus Nitzschia Hassall to genus Psammodictyon D.G. Mann (Bacillariophyceae). - Journal of Biological Research (Naples) 17: 148.

GuirY, M.D. \& GuIRY, G.M. (2019): AlgaeBase. World-wide electronic publication, National University of Ireland, Galway. - http://www.algaebase.org; searched on 23 September 2019 .

Meister, F. (1937): Seltene und neue Kieselalgen. II. - Berichte der Schweizerischen Botanischen Gesellschaft 47: 258-276, 11 pls.

Pankow, H. (1976): Algenflora der Ostsee. II. Plankton (einschliesslich benthischer Kieselalgen). -pp. 1-493, 880 figs, 26 pls, Gustav Fischer, Jena.

Rimet, F.; Kermarrec, L.; Bouchez, A.; Hoffmann, L. \& MedLIN, L.K. (2011): Molecular phylogeny of the family
Bacillariaceae based on 18s rdna sequences: Focus on freshwater Nitzschia of the section Lanceolatae. Diatom Research 26: 1-20.

Round, F.E.; Crawford, R.M. \& Mann, D.G. (1990): The diatoms biology and morphology of the genera. - pp. [i-ix], 1-747, Cambridge University Press, Cambridge.

Sims, P.A. (1996): An atlas of British diatoms arranged by B. Hartley based on illustrations by H.G. Barber and J.R. Carter. - pp. [2], 1-601, incl. 290 pls, Biopress ltd, Bristol.

SPAulding, S. (2011): Tryblionella. In Diatoms of North America. Retrieved December 18, 2019, from https:// diatoms.org/genera/tryblionella.

WANG, Q.X. \& You, Q.M. (2018): Flora algarum sinicarum aquae dulcis (Tomus XXII): BacillariophytaAulonoraphidinales. - 166 pp., Science Press, Beijing.

You, Q.M.; KocioleK, J.P.; CAI, M.J.; Lowe, R.L.; LiU, Y. \& WANG, Q.X. (2017): Morphology and ultrastructure of Sellaphora constrictum sp. nov. (Bacillariophyta), a new diatom from southern China. - Phytotaxa 327: 261-268. DOI: https://doi.org/10.11646/phytotaxa.327.3.5.

(C) Czech Phycological Society (2020)

Received December 27, 2019

Accepted May 13, 2020 